\title{
Effects of phenols, gibberellic acid and carbohydrates on the rooting of the apple rootstock M9 Jork
}

\author{
E Caboni, G Boumis, C Damiano * \\ Fruitculture Research Institute, via di Fioranello, 5200040 Ciampino Aeroporto, Rome, Italy
}

(COST Meeting, 21-23 May 1992, Dijon, France)

\begin{abstract}
Summary - The rooting of the apple rootstock M9 Jork was increased by addition of phloroglucinol (162 mgll) during rooting in the light in presence of $2 \mathrm{mg} / \mathrm{l}$ IBA. Other phenols (catechol, chlorogenic acid, $p$-coumaric acid and quercetin) did not show the same synergic effect. Phloroglucinol had no effect when added during the multiplication stage. $\mathrm{GA}_{3}$ added during multiplication enhanced the rooting ability somewhat at a low concentration (1 mg/l), but was inhibitory at higher dosages. Sorbitol when used as carbon source during multiplication gave the best results in comparison with other sugars. Peroxidase activity was lower in the microcuttings rooted with the addition of phloroglucinol than in those grown in the presence of the other phenols or without phenols. Electrophoretic patterns of isoperoxidases did not show any particular changes due to the treatments.
\end{abstract}

in vitro rooting / carbon source / peroxidase

Résumé - Effets du phenol, de l'acide gibbérellique et des glucides sur l'enracinement du pommier portegreffe M9 Jork. La capacité à l'enracinement du porte greffe M9 Jork du pommier a été augmentée par un traitement avec du phlorog/ucinol (162 mg/l) quand linduction à l'enracinement des microboutures a été faite en présence de $2 \mathrm{mg} /$ de $A / B$ et une photopériode de $16 \mathrm{~h}$. D'autres composés phénoliques, catéchol, acide chlorogénique, acide pcoumarique et quercétine ne montrèrent pas les mêmes effets synergiques.

Des résultats variables suivant la dose ont été obtenus avec l'utilisation de $\mathrm{GA}_{3}$ alors que le sorbitol utilisé comme source de carbone donnait les meilleurs résultats.

L'activité péroxidasique était inférieure dans les microbutures enracinées avec l'addition de phloroglucinol à celle des boutures mises en présence d'autres phénols ou sans phénols. Les spectres isopéroxydasiques ne montrèrent aucun changement dû aux différents traitements.

enracinement in vitro / source de carbone / peroxydase

\section{INTRODUCTION}

The rooting ability of apple cuttings is highly genotype-dependent and the response to rooting treatments is variable (Zimmerman and Broome, 1981). A large number of investigations have been made on the effect of exogenous phenols added to the rooting medium, but with contradictory results: the widely used phloroglucinol is successful in some cases (James and Thurbon, 1979, 1981; Zimmerman, 1984), but has no effect or is even inhibitory in other instances (Zimmerman and Broome, 1981; Zimmerman and Fordham, 1985). The rooting process is regulat- ed, among other substances, by auxin. Enzymes such as peroxidases, IAA-oxidase and polyphenoloxidases are implicated in IAA catabolism and in the oxidation of phenols which act as rooting cofactors or inhibitors. The effect of phenols and other cofactors depends on the interaction between these molecules and the enzymes implicated in the IAA-metabolism during the rooting process. It seems that monophenols and metadiphenols activate IAA-oxidase, and that paradiphenols, ortho-diphenols and polyphenols inhibit it (Reinecke and Bandurski, 1990).

The aim of this study was to investigate the effect of various treatments during the multiplica-

\footnotetext{
* Correspondence and reprints
} 
tion and rooting phase. We also determined peroxidase activity in order to examine the biochemical relationship between the treatments and their effect on rooting.

\section{MATERIALS AND METHODS}

Microshoots of the apple rootstock M9 Jork multiplied on MS medium with sucrose $10 \mathrm{~g} / \mathrm{l}$, sorbitol $20 \mathrm{~g} / \mathrm{l}$, IBA $0.1 \mathrm{mg} / \mathrm{l}, \mathrm{BAP} 0.5 \mathrm{mg} / \mathrm{l}$, agar $6.5 \mathrm{mg} / \mathrm{l}, \mathrm{pH} 5.6$ and rooted on a medium as indicated in table $\mathrm{I}$, were used. Temperature was $24{ }^{\circ} \mathrm{C}$, light intensity was $25 \mu \mathrm{mol}$ $\mathrm{m}^{-2} \mathrm{~s}^{-1}$, with a photoperiod of $16 \mathrm{~h}$. The following treatments, on 60 shoots divided into 3 replicates, were applied:

- darkness during the first $7 \mathrm{~d}$ of rooting;

- phloroglucinol (PGL, polyphenol) $162 \mathrm{mg} / \mathrm{l}$ during the rooting phase, with or without $2 \mathrm{mg} / \mathrm{IBA}$;

- phenols; catechol (o-diphenol), quercetin (odiphenol), chlorogenic acid (CGA, o-diphenol) and $p$ coumaric acid (monophenol) $1 \mathrm{mM}$ during the rooting phase;

- PGL $162 \mathrm{mg} / \mathrm{l}$ in the multiplication medium, followed by rooting with or without $P G L$ at 162 or $1620 \mathrm{mg} /$;

- multiplication with sucrose $10 \mathrm{~g} / \mathrm{l}$ replacing sorbitol with equimolar quantities of fructose, glucose, maltose or galactose, followed by rooting with PGL $162 \mathrm{mg} /$;

- multiplication with $\mathrm{GA}_{3}$ et 1,2 or $4 \mathrm{mg} / \mathrm{l}$ added to the medium before autoclaving, followed by rooting with PGL $162 \mathrm{mg} / \mathrm{l}$

Peroxidase activity was analyzed as follows. Samples of $200 \mathrm{mg}$ of the basal part of the stems of the microcuttings were homogenized in $1.5 \mathrm{ml} 0.06 \mathrm{M}$ phosphate buffer, $\mathrm{pH} 6.1$ with $150 \mathrm{mg}$ polyvinyl-

Table I. M9 Jork rooting medium composition.

\begin{tabular}{|c|c|c|c|}
\hline Macro & Lepoivre & $1 / 2$ & \\
\hline Micro & Lepoivre & Full & \\
\hline FeNaEDTA & & 40 & $\mathrm{mg} / \mathrm{l}$ \\
\hline Nicotinic acid & & & $5 "$ \\
\hline Pyridoxine & & & $5 "$ \\
\hline Thiamine $\mathrm{HCl}$ & & 1 & $"$ \\
\hline Inositol & & 100 & $"$ \\
\hline Riboflavin & & 1 & " \\
\hline Proline & & 100 & $"$ \\
\hline Sucrose & & 30 & $g / 1$ \\
\hline Agar & & 6 & \\
\hline $\begin{array}{l}\text { IBA } \\
\mathrm{pH} 5.6\end{array}$ & & 2 & $\mathrm{mg} / \mathrm{l}$ \\
\hline
\end{tabular}

Lepoivre $=$ Quoirin et al, 1977. polypyrrolidone and centrifuged at $10000 \mathrm{~g}$ for $10 \mathrm{~min}$ to extract the enzymes. Peroxidase activity was detected using guaiacol and $\mathrm{H}_{2} \mathrm{O}_{2}$ as substrates in phosphate buffer $\mathrm{pH} 6.1$. The increase in absorbance at $470 \mathrm{~nm}$ was measured (Angelini et al, 1990). Electrophoresis was performed using starch gel and lithiumborate buffer, $\mathrm{pH} 8.3$ (Quarta and Arnone, 1987); isoelectric focusing was also applied using Servalyte precotes, $\mathrm{pH}$ 3-10 (Serva). Peroxidases were stained by amino-ethyl-carbazole or by benzidine with $\mathrm{H}_{2} \mathrm{O}_{2}$ in acetate buffer $\mathrm{pH} 4.5$ (Vallejos, 1983).

\section{RESULTS}

\section{Treatments during the rooting phase}

The rooting percentage of $\mathrm{M} 9$ Jork was $30 \%$ with $2 \mathrm{mg} / \mathrm{IBA}$ in the light. Culture for $7 \mathrm{~d}$ in the dark did not increase rooting, and callus production was higher (table II, fig 1).

Good results were obtained with the addition of $162 \mathrm{mg} / \mathrm{l} \mathrm{PGL}$ during the rooting phase: it showed a synergic effect with IBA and increased rooting percentage both in the dark and in the light (fig 2). A higher dosage (1620 mg/l) was inhibitory. Other phenols, such as catechol and CGA seemed to stimulate rooting somewhat when added to rooting media without IBA (table II). Their use together with the auxin had an inhibitory effect on the outgrowth of the roots (table II, fig 3). p-Coumaric acid was tested only with IBA in the light; it gave results similar to that of the other phenols (rooting 30\%, $2.0 \pm 0.3$ roots per shoot), but the roots were more evident, although still very short.

\section{Treatments during the multiplication phase}

The use of PGL as pretreatment during multiplication did not improve the results: after 1 or 2 subcultures, rooting was the same as the control. The effect of PGL during the rooting phase was more evident without pretreatment (data not shown).

The multiplication rate decreased somewhat when sorbitol was replaced by other carbohydrates (table III), and no substantial differences were induced by gibberellic acid (fig 4). The dosage of $1 \mathrm{mg} / \mathrm{G} \mathrm{GA}_{3}$ during multiplication seemed to promote rooting on medium containing PGL at $162 \mathrm{mg} / \mathrm{l}$, increasing the percentage from 67.4 to $75 \% . \mathrm{GA}_{3}$ at dosages of 2 and $4 \mathrm{mg} / \mathrm{l}$ inhibited rooting (rooting percentages $\approx 50-55 \%$ ) (fig 4 ). 


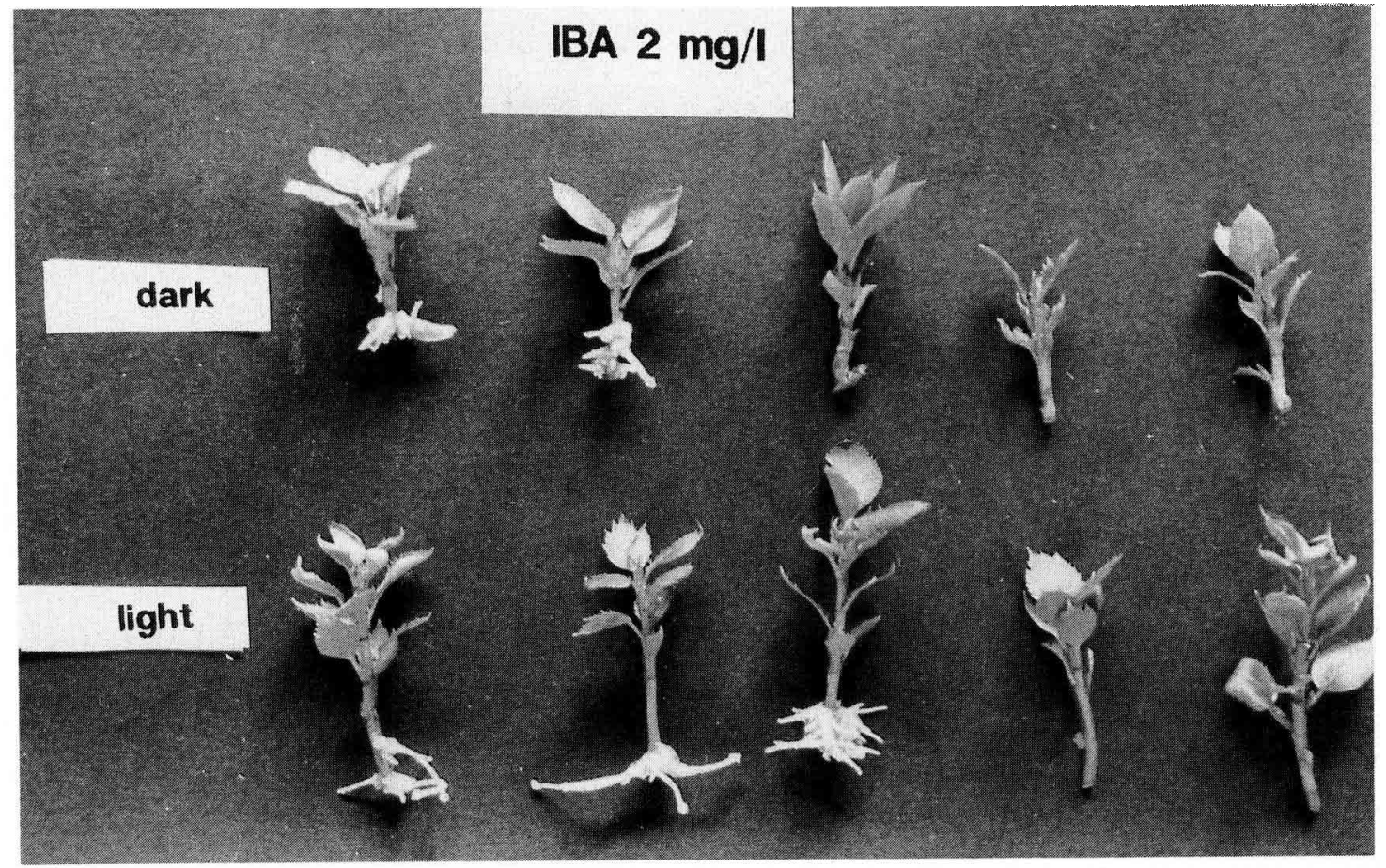

Fig 1. Rooting of M9 Jork, effect of dark treatment during the 1st wk of rooting.

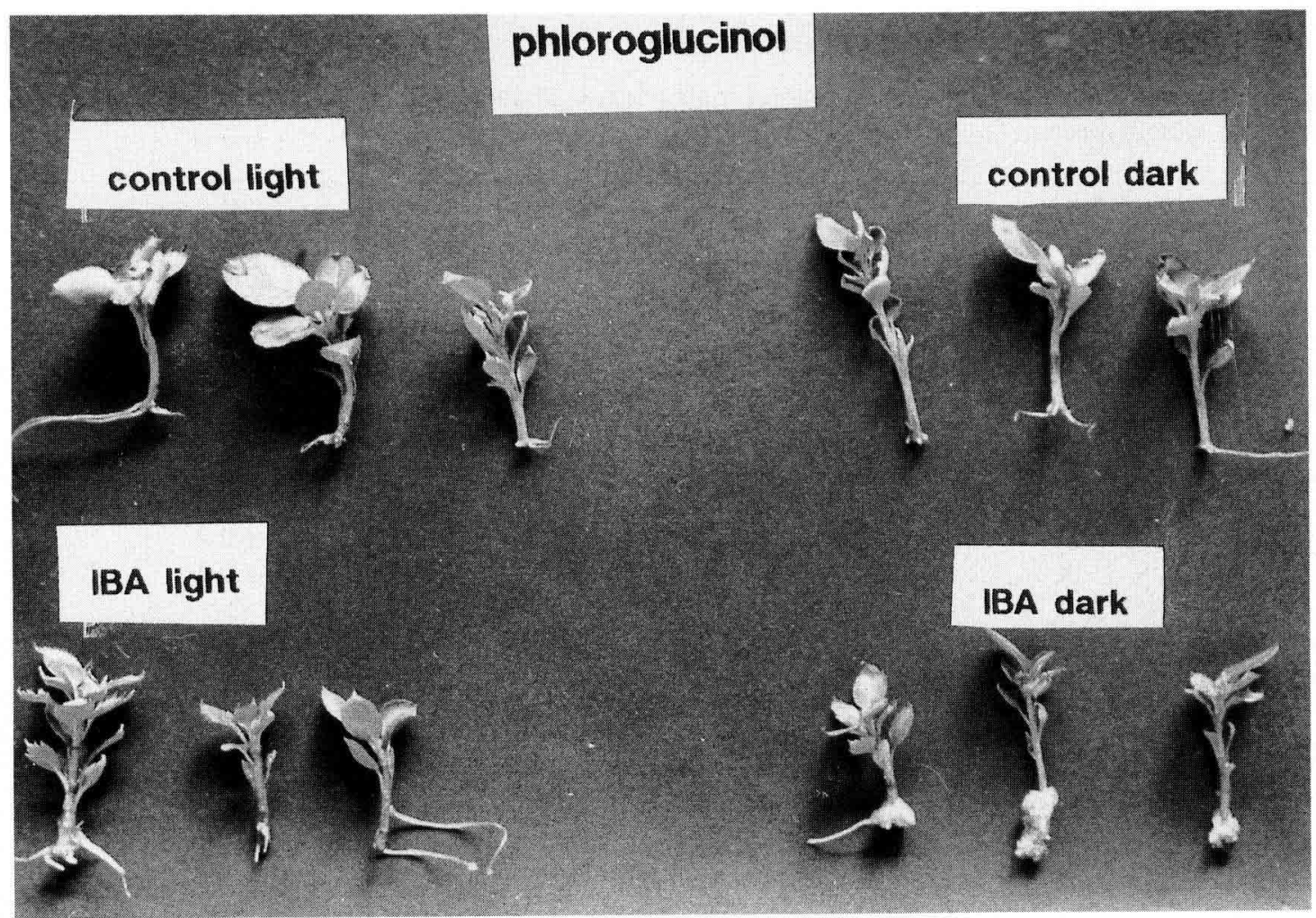

Fig 2. Rooting of M9 Jork with PGL $1 \mathrm{mM}$, with or without IBA $2 \mathrm{mg} / \mathrm{l}$, in the light or with $7 \mathrm{~d}$ in the dark. 


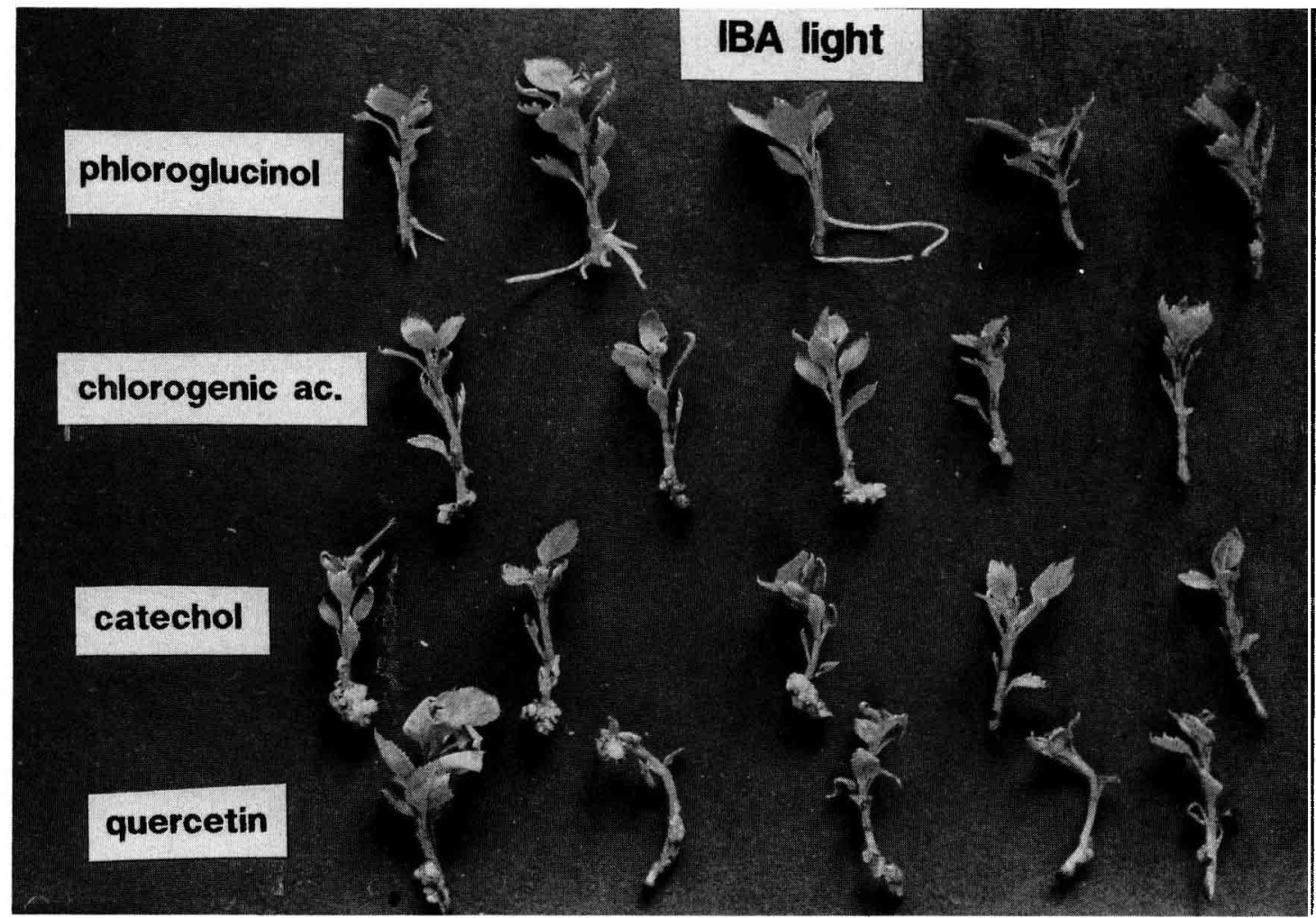

Fig 3. Rooting of M9 Jork with 4 phenols at $1 \mathrm{mM}$, in the light with IBA $2 \mathrm{mg} / \mathrm{l}$.

Table II. Rooting of M9 Jork: percentage, number of roots per rooted shoot and length of roots (mm) on medium with IBA $2 \mathrm{mg} / \mathrm{l}$ and without auxin.

\begin{tabular}{|c|c|c|c|c|c|c|}
\hline & \multicolumn{3}{|c|}{$I B A 2 \mathrm{mg} /$} & \multicolumn{3}{|c|}{ No auxin } \\
\hline & $\%$ & $\begin{array}{l}\text { No roots } \\
\text { per shoot }\end{array}$ & Length & $\%$ & $\begin{array}{l}\text { No roots } \\
\text { per shoot }\end{array}$ & Length \\
\hline PGL light & 60 & $3.5 \pm 0.4$ & $4.5 \pm 0.5$ & 40 & $3.3 \pm 0.1$ & $9.3 \pm 0.9$ \\
\hline PGL dark & 25 & $2.0 \pm 0.4$ & $4.0 \pm 0.6$ & 35 & $3.9 \pm 0.1$ & $6.0 \pm 0.2$ \\
\hline CGA light & 25 & ND & * & 25 & $2.6 \pm 0.2$ & $12.9 \pm 0.4$ \\
\hline CGA dark & 30 & ND & * & 10 & $1.0 \pm 0.1$ & $20.0 \pm 1.0$ \\
\hline Catechol light & 40 & ND & * & 15 & $2.2 \pm 0.3$ & $11.6 \pm 2.0$ \\
\hline Catechol dark & 25 & ND & * & 0 & - & - \\
\hline Quercetin light & 25 & ND & * & 10 & $1.0 \pm 0.3$ & $4.0 \pm 0.6$ \\
\hline Quercetin dark & 10 & ND & * & 0 & - & - \\
\hline Control light & 30 & $9.5 \pm 0.8$ & $5.6 \pm 0.9$ & 0 & - & - \\
\hline Control dark & 15 & $5.5 \pm 1.2$ & $3.1 \pm 1.0$ & 0 & - & - \\
\hline
\end{tabular}

ND: not determined as the roots were too short; * non developed roots. 
Table III. Multiplication rate of M9 Jork during a subculture (20 d) with different carbohydrate types.

$\begin{array}{ll}\text { Sucrose + sorbitol } & 2.7 \pm 0.2 \\ \text { (control) } & 2.7 \pm 0.4 \\ \text { Sucrose + galactose } & 2.5 \pm 0.4 \\ \text { Sucrose + maltose } & 2.2 \pm 0.4 \\ \text { Sucrose + fructose } & 2.2 \pm 0.3 \\ \text { Sucrose + glucose } & \end{array}$

\section{Peroxidase activity}

Analyses of peroxidase activity were made during the rooting process. The addition of IBA had practically no effect on peroxidase activity (fig 5 ). The addition of PGL, which increased rooting, resulted in a lower peroxidase activity with respect to other phenols such as catechol and $p$ coumaric acid and the use of IBA alone (figs 5, 6). The electrophoretic patterns did not show particular polymorphism due to the treatments.

\section{DISCUSSION AND CONCLUSION}

The satisfactory results for rooting obtained in the light are in contrast with the observations of other authors (Zimmerman, 1984; Zimmerman and Fordham, 1985), who found a beneficial effect due to a short period of growth in darkness. In our experiments the shoots rooted in the light show less callus formation than those rooted af-

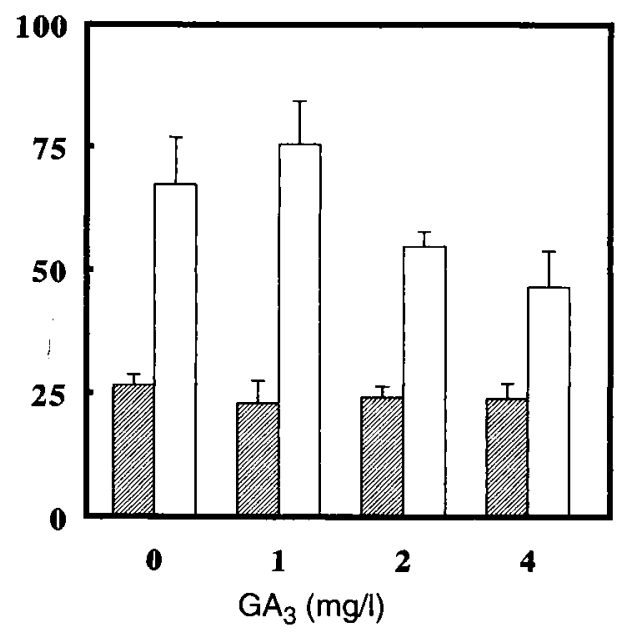

Fig 4. Multiplication rate $(\times 10)(\not Z)$ and rooting percentage ( $\square$ ) with IBA $2 \mathrm{mg} / \mathrm{l}, \mathrm{PGL} 162 \mathrm{mg} / \mathrm{l}$ in the light, after subculture with 3 dosages of $\mathrm{GA}_{3}$. ter a short period in darkness; this fact could be explained by the presence of riboflavin, which accelerates the photodegradation of IBA (van der Krieken et al, 1992).

$P G L$ seems to be effective only when added in the rooting medium: other observations on the use of this phenol during the multiplication phase showed a negative effect on rooting (Damiano et al, 1991). Other phenols used in the present experiments did not show the same synergic effect with IBA as PGL did. This confirms the results of Jones and Hatfield (1976), who also found catechol to be less effective than PGL. Regarding certain positive effects of PGL and other phenols in the absence of exogenous

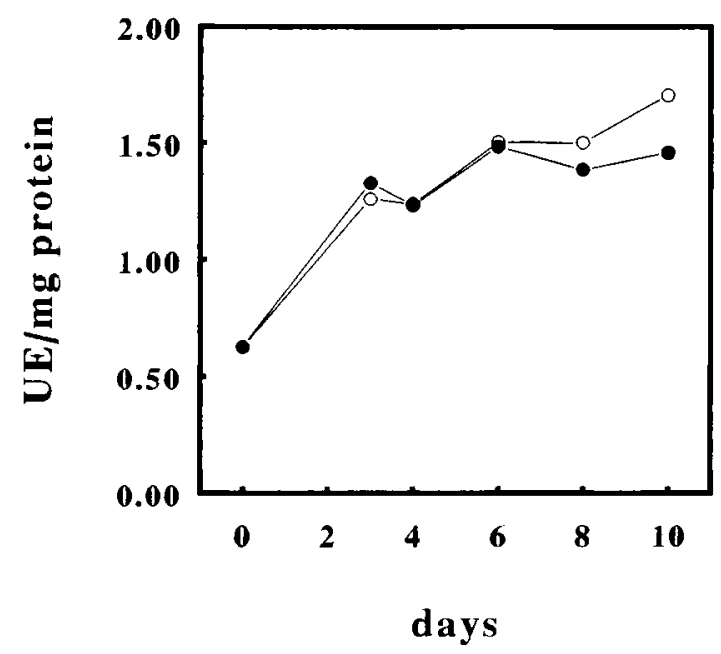

Fig 5. Rooting of M9 Jork, peroxidase activity during rooting without auxin ( $\longrightarrow-$ control) or with IBA $2 \mathrm{mg} / \mathrm{C}(\longrightarrow)$ in the light.

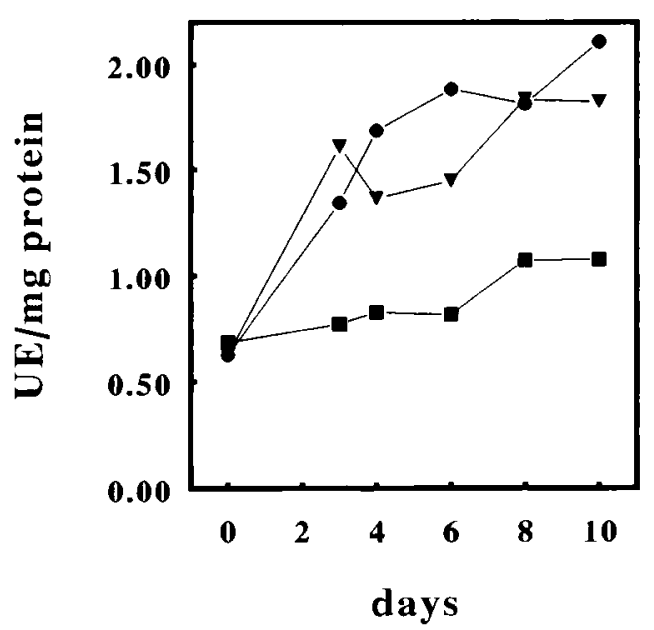

Fig 6. Rooting of $M 9$ Jork, peroxidase activity during rooting with 3 phenols $1 \mathrm{mM}$ with IBA $2 \mathrm{mg} / \mathrm{l}$ in the light; - - catechol; - $\nabla$-p-coumaric; $\rightarrow$ - PGL. 
auxins, it may be suggested that in our case the endogenous auxin level was probably increased by the presence of these phenols.

The $\mathrm{GA}_{3}$ treatments provided contradictory results. After the experiments by Brian et al (1960), many other results have confirmed the inhibitory effect of $\mathrm{GA}_{3}$ on rooting. However, the effects seem to be correlated with the time of application; in fact, $\mathrm{GA}_{3}$ regulates the activity of IAAoxidase and therefore controls the endogenous auxin level (Gaspar et al, 1977). The effect on rooting ability is less clear when $\mathrm{GA}_{3}$ is applied during the multiplication phase, although we found a small positive effect at the lowest concentration used.

Our findings show that peroxidase activity without auxin is similar to that with IBA. We also found no clear peaks: peroxidase activity did not decrease. Both sets of data seem to be in contrast with the results of Gaspar et al (1990). In this regard it may be advisable to extend the investigation to the first days of rooting, indicated by Gaspar as the critical period for the biochemical changes before rooting expression.

\section{ACKNOWLEDGMENTS}

This study was funded by the Ministry of Agriculture in the Special Project "Biotechnology in Agriculture". The authors than B Kunneman, Research Station for Nursery Stock, Boskoop, The Netherlands, for the supply of M9 Jork microcuttings.

\section{REFERENCES}

Angelini R, Manes F, Federico R (1990) Spatial and functional correlation between diamine-oxidase and peroxidase activities and their dependence upon de-etiolation and wounding in chick-pea stems. Planta 182, 89-96

Brian PW, Hemming HG, Lowe D (1960) Inhibition of rooting of cuttings by gibberellic acid. Ann Bot 24, 407-409

Damiano C, Chiariotti A, Caboni E, Quarta R, Boumis $G$ (1991) Some factors affecting the induction and the expression of rooting in different fruit species in vitro. Acta Hortic 300, 211-224

Gaspar T, Smith D, Thorpe T (1977) Arguments supplémentaires en faveur d'une variation inverse du niveau auxinique endogène au cours de deux premières phases de la rhizogenèse. $C A$ Acad Sci Paris 825, 327-330

Gaspar T, Moncousin C, Greppin H (1990) The place and role of exogenous and endogenous auxin in adventitious root formation. In: Intra- and Intercellular Communication in Plants (Millet B, Greppin $\mathrm{H}$, eds) INRA, Paris, 125-139

James DJ, Thurbon IJ (1979) Rapid in vitro rooting of the apple rootstock M9. J Hortic Sci 54, 309-311

James DJ, Thurbon IJ (1981) Shoot and root initiation in vitro in the apple rootstock M9 and the promotive effects of phloroglucinol. J Hortic Sci 56, 15-20

Jones OP, Hatfield GS (1976) Root initiation in apple shoot cultured in vitro with auxin and phenolic compounds. J Hortic Sci 51, 495-499

Quarta R, Arnone S (1987) Peroxidase polymorphism in apple cultivars. Adv Hortic Sci 1, 83-86

Quoirin M, Lepoivre P, Boxus P (1977) Un premier bilan de 10 années de recherches sur les cultures de méristèmes et la multiplication in vitro de fruitiers ligneux. In: C R Rech 1976-1977 Rapport Synthese, Stat Cult Fruit et Maraich, Gembloux. 93-97

Reinecke DM, Bandurski RS (1990) Auxin biosynthesis and metabolism. In: Plant Hormones and their Role in Plant Growth and Development (Davies PJ, ed) Kluwer Academic Publ, Dordrecht, 24-42

Vallejos CE (1983) Enzyme activity staining. In: Isozymes in Plant Genetics and Breeding. Part A (Tanksley SD, Orton TJ, eds) Elsevier, Amsterdam, 469-516

van der Krieken VM, Breteler $\mathrm{H}$, Visser MHM, Jordi $\mathrm{W}$ (1992) Effect of light and riboflavin on indolebutyric acid-induced root formation on apple in vitro. Physiol Plant (in press)

Zimmerman $\mathrm{RH}$ (1984) Rooting apple cultivars in vitro interactions among light, temperature, phloroglucinol and auxin. Plant Cell Tissue Organ Cult 3, 301311

Zimmerman $\mathrm{RH}$, Broome OC (1981) Phloroglucinol and in vitro rooting of apple cultivar cuttings. $J \mathrm{Am}$ Soc Hortic Sci 106, 648-652

Zimmerman RH, Fordham I (1985) Simplified method for rooting apple cultivars in vitro. J Am Soc Hortic Sci $110,34-38$ 